\title{
Nerve Growth Factor Signaling through p75 Induces Apoptosis in Schwann Cells via a Bcl-2-Independent Pathway
}

\author{
Merja Soilu-Hänninen,, ${ }^{1}$ Paul Ekert, ${ }^{1}$ Tamara Bucci, ${ }^{1}$ Daniel Syroid, ${ }^{2}$ Perry F. Bartlett, ${ }^{1}$ and \\ Trevor J. Kilpatrick ${ }^{1}$ \\ ${ }^{1}$ The Walter and Eliza Hall Institute of Medical Research, The Royal Melbourne Hospital, Parkville Victoria 3050, Australia, \\ and ${ }^{2}$ The Salk Institute for Biological Studies, La Jolla, California 92186-5800
}

Apoptosis is involved in the regulation of Schwann cell numbers during normal development and after axonal damage, but the molecular regulation of Schwann cell death remains unknown. We have used stably transfected rat Schwann cell lines to study the potential roles of nerve growth factor (NGF), the antiapoptotic protein $\mathrm{Bcl}-2$ and the cytokine response modifier $\mathrm{A}(\mathrm{CrmA})$ in modulating Schwann cell death in vitro. Bcl-2 inhibited Schwann cell apoptosis induced by survival factor withdrawal, whereas CrmA did not. In contrast, Bcl-2-transfected Schwann cells were susceptible to apoptosis in response to exogenous NGF, whereas CrmA-expressing cell lines were resistant. Demonstration of high levels of the low-affinity neurotrophin receptor p75 but not the high-affinity TrkA receptor on the Bcl-2transfected cell lines suggested that the NGF-induced killing was mediated by p75. This was confirmed by resistance of Schwann cells isolated from p75 knockout mice to the NGFinduced cell death. Nerve growth factor also promoted the death of wild-type mouse and rat Schwann cells in the absence of survival factor withdrawal. Endogenous Bcl-2 mRNA was expressed by wild-type Schwann cells in all conditions that promoted survival but was downregulated to undetectable levels after survival factor withdrawal. In conclusion, our results demonstrate the existence of two separate pathways that expedite apoptosis in Schwann cells: a Bcl-2-blockable pathway initiated on loss of trophic support, and a Bcl-2-independent, CrmA-blockable pathway mediated via the p75 receptor.

Key words: apoptosis; neurotrophins; Schwann cells; nerve growth factor; Bcl-2; low-affinity neurotrophin receptor
The number of Schwann cells in peripheral nerve is tightly regulated, and programmed cell death, or apoptosis, has been implicated in this process (Syroid et al., 1996; Trachtenberg and Thompson, 1996). Axonally derived neuregulins prevent Schwann cell apoptosis, suggesting that Schwann cell numbers are controlled by competition for axonally derived trophic support (Grinspan et al., 1996). However, the molecules involved in mediating Schwann cell apoptosis are unknown.

Apoptosis involves activation of a cascade of proteolytic enzymes called caspases (Nicholson and Thornberry, 1997). Members of the Bcl-2 protein family are key regulators of apoptosis and are categorized according to their ability to promote (e.g., Bak, Bax, Bik) or inhibit (e.g., Bcl-2, Bcl-xL, Bcl-w) apoptosis (Newton and Strasser, 1998). The mechanism of the antiapoptotic function of $\mathrm{Bcl}-2$ is uncertain, but $\mathrm{Bcl}-2$ proteins regulate the activation of key caspases (Adams and Cory, 1998; Newton and Strasser, 1998). Recently, it was suggested that Bcl-2 could also serve as a caspase substrate, such that activation of the cell surface receptor Fas (Itoh et al., 1991) leads to cleavage of

\footnotetext{
Received Dec. 14, 1998; revised March 8, 1999; accepted April 7, 1999.

This work was supported by the National Health and Medical Research Council (NH\&MRC) of Australia and the Sylvia and Viertel Charitable Foundation. M.S.-H. was supported by grants from the Finnish Multiple Sclerosis Society, the Finnish Cultural Foundation, the Academy of Finland, and the Maud Kuistila Foundation. P.E. was supported by a NH\&MRC postgraduate scholarship. We thank Dr. Duanzhi Wen (Amgen Inc.) for the neuregulin- $\beta$ and Dr. Greg Lemke (Salk Institute) for the $\mathrm{P}_{0}$ probe. We also thank Dr. David Vaux and the members of his laboratory for helpful discussions, for their kind gifts of CrmA and Bcl-2 plasmids, and for critical reading of this manuscript. Mrs. Radmilla Milekic is acknowledged for secretarial assistance in the preparation of this manuscript.

Correspondence should be addressed to Trevor J. Kilpatrick, The Walter and Eliza Hall Institute of Medical Research, Post Office The Royal Melbourne Hospital, Parkville Victoria 3050, Australia.

Copyright (C) 1999 Society for Neuroscience 0270-6474/99/194828-11\$05.00/0
}

Bcl-2, which then accelerates rather than inhibits apoptosis (Cheng et al., 1997).

Schwann cells express high levels of the low-affinity neurotrophin receptor p75 (Lemke and Chao, 1988), which has sequence similarity to the tumor necrosis factor receptor (TNFR) p $55^{\text {TNFR }}$ and to Fas (Meakin and Shooter, 1992). Ligand binding to Fas or p55 $5^{\text {TNFR }}$ initiates programmed cell death via activation of caspase 8, which can cleave other caspases. This caspase 8-mediated pathway cannot be blocked by Bcl-2 but is inhibitable by a poxvirus caspase inhibitor, cytokine response modifier A (CrmA) (Chinnaiyan et al., 1995; Strasser et al., 1995; Cohen, 1997). A role for $\mathrm{p} 75$ in signaling the death of neural cells has also been established (Rabizadeh et al., 1993; Barrett and Bartlett, 1994; Frade et al., 1996; Frade and Barde, 1998), but the role of ligand binding in p75 activation is uncertain. In some systems, p75 induces cell death constitutively (Rabizadeh et al., 1993), whereas cell death can also be induced by p75 activation through ligand binding (Casaccia-Bonnefil et al., 1996; Frade et al., 1996). The intracellular death pathway initiated by p 75 signaling is unknown.

The neurotrophins not only bind to p75 but also bind with high affinity to receptor tyrosine kinases known as Trks, comprising Trk-A, -B, and -C (Kaplan et al., 1991; Kaplan and Miller, 1997). Potential mechanisms by which the prototypic neurotrophin, nerve growth factor (NGF), signals were recently assessed in oligodendrocytes; it was suggested that activation of Trk-A promoted survival via activation of NF-kB and via suppression of a death signal delivered by p75, acting through c-jun kinase (Yoon et al., 1998). It is of note that Schwann cells express only low levels of the Trk receptors (Yamamoto et al., 1993).

The role of p75 in Schwann cells is obscure. Schwann cells could possibly bind and present NGF to regenerating neurons 


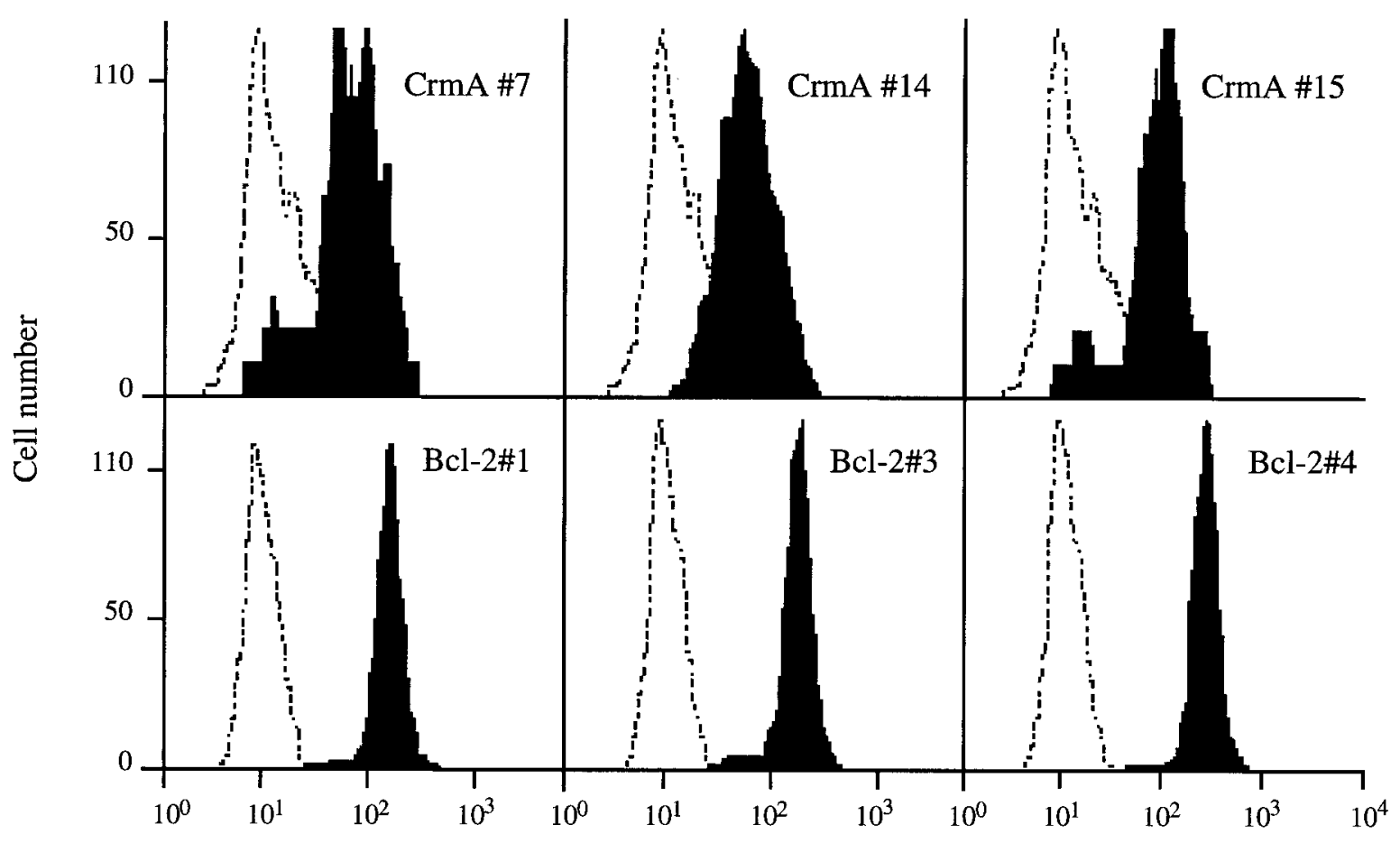

\section{Log Fluorescence}

Figure 1. Intracellular expression of the human Bcl-2 protein and the poxvirus caspase inhibitor CrmA in the transfected rat Schwann cell lines Bcl-2\#1, -\#3, -\#4, and CrmA\#7, \#14, and \#15. Immunofluorescence staining was performed with the mouse mAb Bcl-2-100 against the human Bcl-2 (for the Bcl-2 cell lines) or with mouse anti-Flag mAb (for the CrmA cell lines), and binding of primary antibody was detected with FITC-conjugated sheep anti-mouse IgG. As negative controls, rat Schwann cells transfected with the empty expression plasmid pEF were similarly stained (indicated in the histograms with a dashed line).

after peripheral axotomy (Heumann et al., 1987), and it has been suggested that NGF could support Schwann cell migration (Anton et al., 1994). There is no compelling evidence, however, to indicate a role for NGF as a Schwann cell survival factor, although NGF can activate NF-kB through p75 (Carter et al., 1996). To date, cell death signaling through $\mathrm{p} 75$ has not been demonstrated in Schwann cells.

In this study, using stably transfected Schwann cell lines, we found that Bcl-2, but not CrmA, protects Schwann cells from apoptosis induced by survival factor withdrawal. In contrast, Schwann cells transfected with Bcl-2 were sensitive to apoptosis in response to exogenous NGF, whereas CrmA-transfected Schwann cells were resistant. Lack of TrkA expression in the Bcl-2-transfected cell lines and resistance of p75-deficient Schwann cells to NGF-induced killing suggested that the NGFinduced death response was mediated via the p75 receptor.

\section{MATERIALS AND METHODS}

Cell culture and transfections. Cultures of rat Schwann cells were prepared from postnatal day 3 sciatic nerve and purified to $>99.5 \%$ homogeneity as described previously (Brockes et al., 1979). Cells were plated on poly-L-lysine-coated $(100 \mu \mathrm{g} / \mathrm{ml}$; Sigma, St. Louis, MO) $10 \mathrm{~cm}$ tissue culture Petri dishes or 6-well plates (Falcon) and maintained in DMEM (Life Technologies, Gaithersburg, MD), 10\% fetal calf serum (FCS) (HyClone, Logan, UT), $2 \mu \mathrm{m}$ forskolin (Sigma), and $10 \mathrm{ng} / \mathrm{ml}$ recombinant human neuregulin- $\beta$ (Amgen, Thousand Oaks, CA). Subconfluent cultures that had been passaged 5-10 times were transfected either by using the transfection reagent LipofectAMINE (Life Technologies) according to the manufacturer's instructions or by electroporation of $2 \times$ $10^{7}$ Schwann cells suspended in $500 \mu \mathrm{l}$ of PBS, at $270 \mathrm{~V}$ and $960 \mu \mathrm{FD}$, with $10 \mu \mathrm{g}$ of plasmid cDNA containing either full-length human Bcl-2 or poxvirus CrmA cloned into the pEF FLAGpGKpuro (pEF) mammalian expression vector (Huang et al., 1997). This vector contains sequences encoding a Flag-tag and puromycin resistance. Both the Bcl-2 and CrmA plasmid cDNAs were kind gifts from Dr. David Vaux (The Walter and Eliza Hall Institute of Medical Research). Puromycin (Sigma) was added to facilitate positive selection at $2 \mu \mathrm{g} / \mathrm{ml} 48 \mathrm{hr}$ after transfection.

Mouse Schwann cells were isolated from postnatal day 2 sciatic nerves of BALB/c mice and homozygous mutant mice deficient for p75 (Lee et al., 1992) backcrossed onto the BALB/c and 129 genetic background. Briefly, nerves were digested for $30 \mathrm{~min}$ at $37^{\circ} \mathrm{C}$ by incubation with $0.25 \%$ trypsin (Sigma) and $0.02 \%$ collagenase (Sigma) in HBSS. Digestion was terminated by addition of $10 \%$ ice-cold FCS. Single-cell suspensions were subsequently prepared by passage of the cells through 18,21 , and 23 gauge needles fitted to a $1 \mathrm{ml}$ syringe. Cells were then pelleted, washed once with DMEM/10\% FCS, and plated on 96-well plate wells in DMEM containing $10 \% \mathrm{FCS}$ and $10 \mathrm{ng} / \mathrm{ml}$ of neuregulin- $\beta$. Cells were expanded for 5-7 d and then sorted using rat anti-mouse Thy 1.2 antibody (Ab) $(10 \times$ concentrated supernatant of hybridoma $30 \mathrm{H} 12)$ and rabbit complement (Life Technologies) to remove contaminating fibroblasts. Sorted cells were washed and plated on poly-L-lysine-coated 24-well plate wells and then subsequently dissociated on the following day to set up viability assays (see below). The percentage of Schwann cells in both the wild-type and knockout cultures was determined after sorting by S-100 staining of cells plated on 8 -well chamber slides. A total of 500 cells/ culture were counted from six to seven separate fields at $40 \times$ magnification, yielding purities of $94 \pm 2 \%$ for the wild-type cultures and $96 \pm$ $3 \%$ for the p75 knockout cultures.

Growth factors. The $\beta$-form of recombinant human neuregulin was obtained from Amgen. Nerve growth factor, purified from male mouse submaxillary glands (mNGF 2.5S; Alomone Labs), was purchased from Sapphire Bioscience (Alexandria, NSW, Australia). Recombinant human insulin-like growth factor (IGF-1) was purchased from Boehringer Mannheim. 

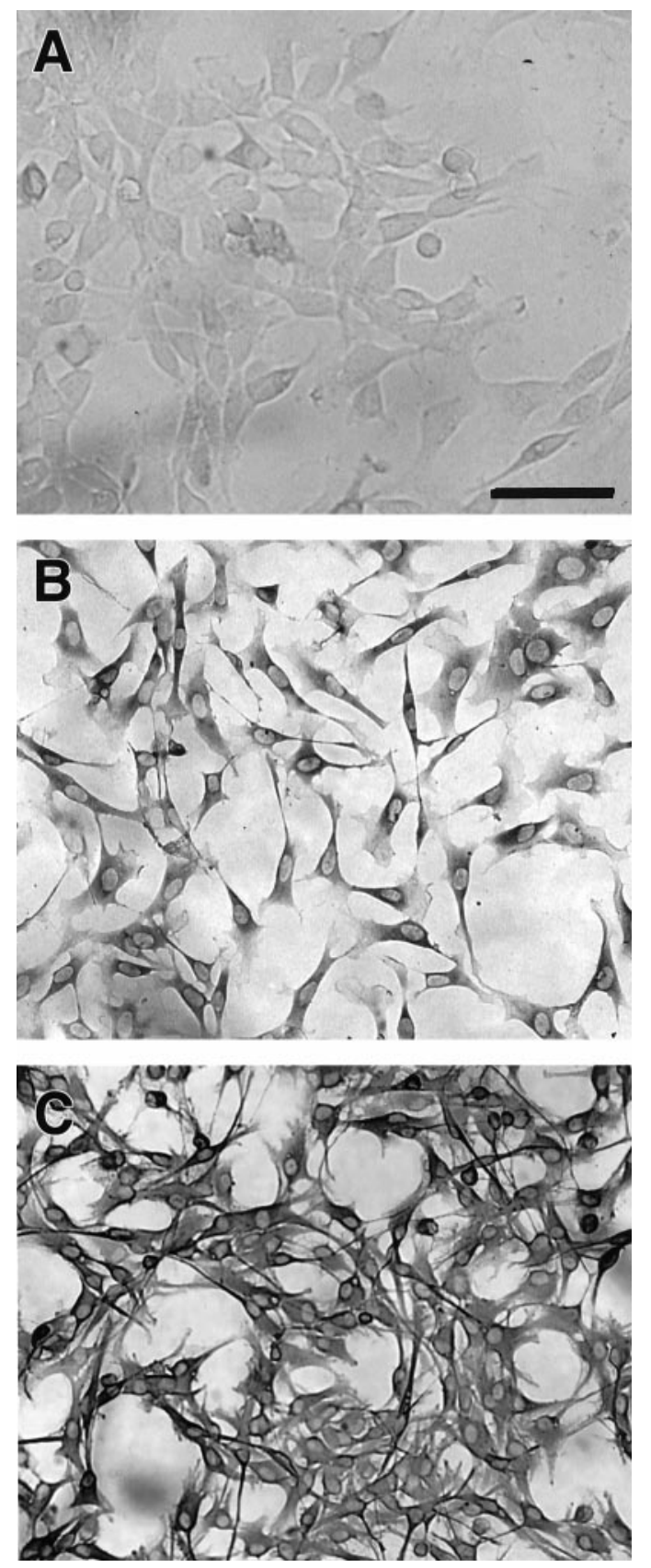

Figure 2. The transfected Schwann cells express the astroglial protein $\mathrm{S}-100$. Immunoperoxidase staining of Bcl-2\#1 cells $(B)$ and CrmA\#14cells $(C)$ with rabbit anti-cow-S-100 protein is shown. As negative controls, the same cell lines were stained with secondary antibody only, as shown for the Bcl-2\#1 cell line in $A$. Scale bar (shown in $A$ ): $A, B, 50 \mu \mathrm{m}$; $C, 100 \mu \mathrm{m}$.

Antibodies and flow cytometry reagents. Monoclonal antibody to the low-affinity nerve growth factor receptor of rat (clone MC192) and a monoclonal antibody to mouse nerve growth factor (clone 27/21, which also reacts with NGF from rat) were purchased from Boehringer Mannheim. Anti-Flag $\mathrm{Ab}$ (clone $\mathrm{M}_{2}$ ) was from Sigma (NSW, Australia). Anti-human Bcl-2 Ab that was used for flow cytometry (DAKO-Bcl-2, clone 124) and rabbit anti-cow-S-100 antibody were from Dako Corporation (Carpinteria, CA). Anti-human Bcl-2 Ab [Bcl-2-100 (Pezzella et al., 1990)] that was used for Western blotting was a kind gift from Dr. David Huang (The Walter and Eliza Hall Institute of Medical Research). Anti-human CD40L monoclonal antibody (mAb; isotype control for the MC192 mAb) was from PharMingen (San Diego, CA). FITC-conjugated

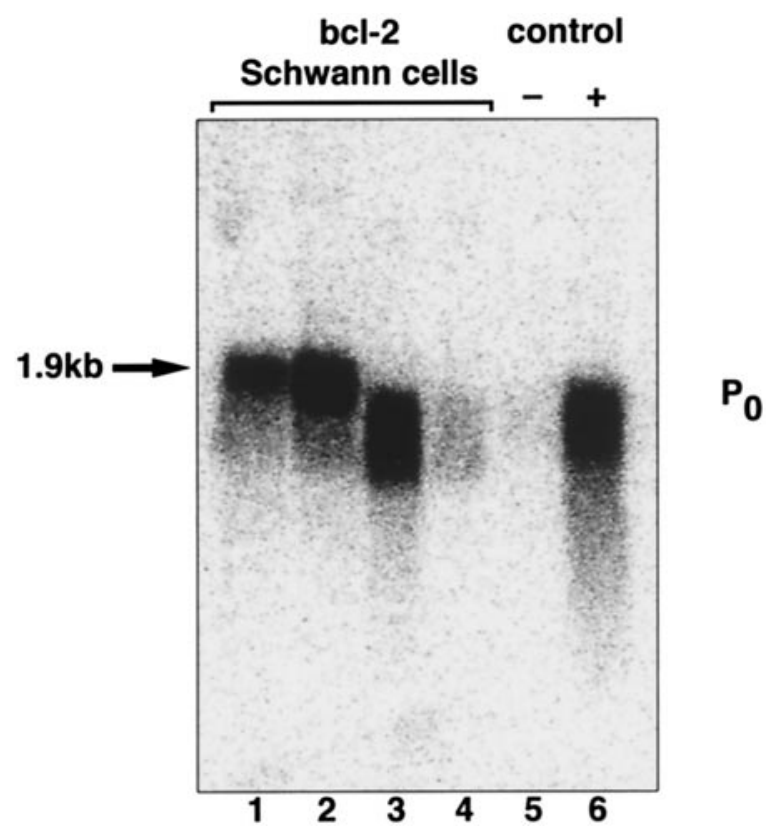

Figure 3. Northern blot analysis confirms that the Bcl-2-transfected cell lines express transcripts of the Schwann cell-specific $\mathrm{P}_{0}$ gene. Shown is $\mathrm{P}_{0}$ expression of the three Bcl-2-transfected cell lines cultured in either high $(20 \mu \mathrm{M}$, lanes 1-3) or low concentration of forskolin $(2 \mu \mathrm{M}, \mathrm{Bcl}-2 \# 1$ cell line, lane 4). Lane 5 contains fibroblast RNA as a negative control, and lane 6 contains wild-type rat Schwann cell RNA as a positive control.

sheep anti-mouse $\operatorname{IgG}$ and FITC-conjugated goat anti-mouse $\mathrm{IgG}$ (Southern Biotechnology Associates, Birmingham, AL) were purchased from Silenius Laboratories (Victoria, Australia). Annexin-V-Fluos reagent, a fluorescence-conjugated anticoagulant for the detection of phosphatidylserine on the outer leaflet of apoptotic cells, was purchased from Boehringer Mannheim.

3-[4,5-Dimethylthiazol-2-yl]-2,5-diphenyltetrazolium bromide survival assay. To assess the survival kinetics of the various transfected rat Schwann cell lines, the cells were first trypsinized and washed three times with ice-cold DMEM. Washed cells were then plated at $4 \times 10^{4}$ cells $/ \mathrm{ml}$ in either DMEM without serum and without growth factors or with DMEM together with either 1,10 , or $100 \mathrm{ng} / \mathrm{ml} \mathrm{NGF,} \mathrm{with} 500 \mathrm{ng} / \mathrm{ml}$ anti-mouse NGF antibody, or $10 \mathrm{ng} / \mathrm{ml} \mathrm{NGF}$ together with $500 \mathrm{ng} / \mathrm{ml}$ anti-NGF. Assays were performed over a $72 \mathrm{hr}$ period in multiple Terasaki microwell plates, such that numbers of viable 3-[4,5dimethylthiazol-2-yl]-2,5-diphenyltetrazolium bromide (MTT)-positive cells were counted at $0,24,48$, and $72 \mathrm{hr}$. Six wells for each time point and each condition were assessed. Cells exhibiting a blue granular reaction product $1 \mathrm{hr}$ after addition of $0.5 \mathrm{mg} / \mathrm{ml}$ MTT were counted as positive. The percentage of surviving cells was then determined as a fraction of the baseline cell count for each experimental condition. Wild-type rat and mouse Schwann cells were similarly assessed, in either DMEM alone, DMEM together with $10 \mathrm{ng} / \mathrm{ml} \mathrm{NGF}$ and, in a subset of experiments, $100 \mathrm{ng} / \mathrm{ml} \mathrm{IGF-1} \mathrm{and} 50 \mathrm{ng} / \mathrm{ml}$ neuregulin- $\beta$ with or without $10 \mathrm{ng} / \mathrm{ml}$ NGF. Because of the limited numbers of mouse Schwann cells, only baseline and $48 \mathrm{hr}$ time points were included.

Statistics. Statistical significance of the differences in survival between Bcl-2 and CrmA-transfected and control cell lines for each of the culture conditions tested was assessed using unpaired Student's $t$ test, with the aid of Microsoft Excel Version 4.0 computer software and the Student Distribution from Geigy Scientific Tables. $p$ values $<0.05$ were taken as statistically significant.

S-100 immunohistochemistry. To analyze for expression of the glial protein S-100, Schwann cells were cultured on 8-well Chamber slides (Nunc, Roskilde, Denmark). The cultures were then fixed with $4 \%$ paraformaldehyde and stained with rabbit anti-cow S-100 antibody at 1:200 dilution. Binding of the primary antibody was detected using a Vectastain peroxidase anti-rabbit IgG kit according to the manufacturer's instructions. A chromogenic reaction was developed with DAB, and the slides were mounted in Gurr's Aquamount (BDH Laboratory Sup- 
A

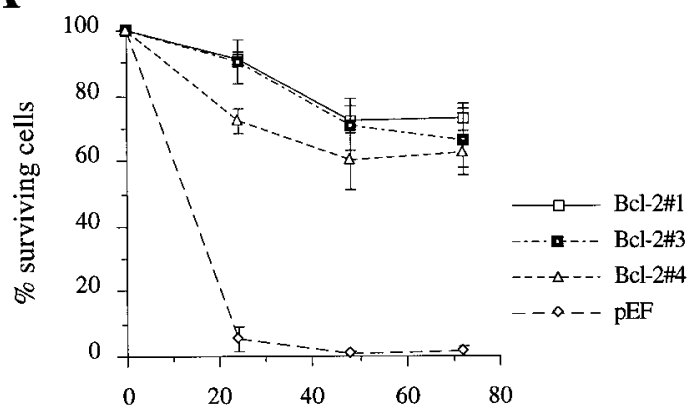

$\mathbf{C}$

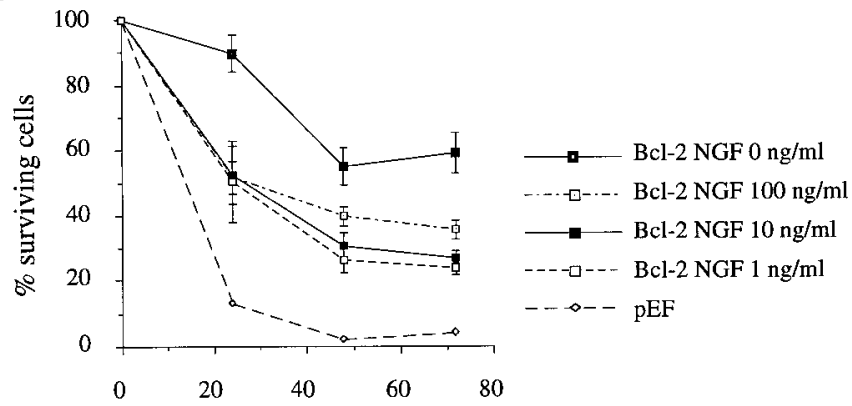

B

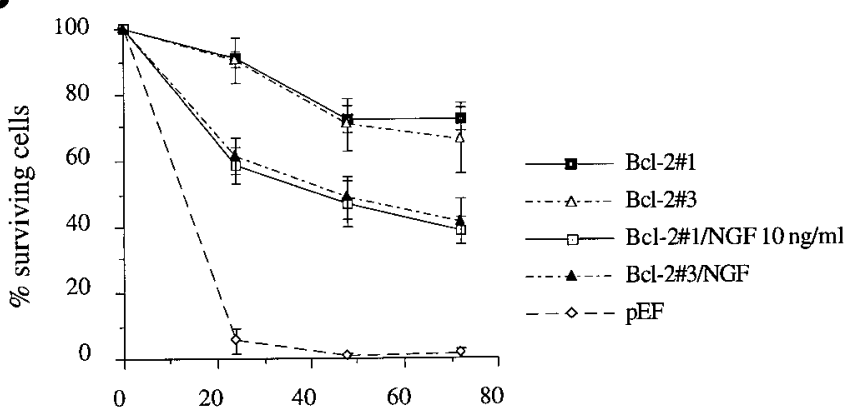

$\mathbf{D}$

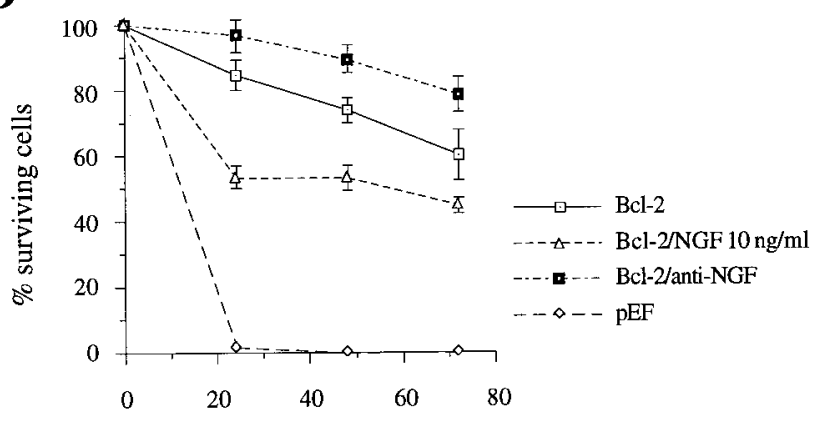

\section{Hours post withdrawal of serum, neuregulin and forskolin}

Figure 4. Survival of Bcl-2-transfected rat Schwann cells in vitro after survival factor withdrawal or treatment with either exogenous NGF or anti-NGF antibodies. The control cells were transfected with the empty mammalian expression vector pEF. Cells were cultured in multiple microwell plates in $(A)$ DMEM only or $(B, C)$ DMEM containing exogenous NGF or $(D)$ anti-NGF antibody. The numbers of viable cells were assessed daily over a $3 \mathrm{~d}$ period. $A$, Bcl-2 protects Schwann cells from apoptosis induced by survival factor withdrawal. The data shown represent means \pm SEM of three independent experiments comparing the survival of three separate Bcl-2-transfected Schwann cell lines $(B c l-2 \# 1, B c l-2-\# 3$, and Bcl-2\#4) with the survival of a control cell line, $p E F$. All three Bcl-2-transfected cell lines exhibited a significant survival advantage at 24,48 , and $72 \mathrm{hr}(p$ values from 0.005 to $<0.0005)$. $B$, Nerve growth factor at $10 \mathrm{ng} / \mathrm{ml}$ significantly reduces the survival of Bcl-2-transfected Schwann cells. Means \pm SEM of three independent experiments with Bcl-2\#1 and -\#3 cell lines and the control cell line pEF\#1 are shown. $p$ values are $0.001,0.01$, and 0.0025 for the Bcl-2\#1 cell line and 0.025 , 0.001, and 0.1 (NS) for the Bcl-2\#3 cell line at 24, 48, and $72 \mathrm{hr}$, respectively. $C$, Dose-response study of the effect of NGF on the survival of Bcl-2-transfected Schwann cells. Shown are mean viabilities \pm SEM of Bcl-2\#1, Bcl-2\#3, and Bcl-2\#4 cell lines assayed in one survival experiment. Culture conditions were either DMEM alone or DMEM with 1, 10, or $100 \mathrm{ng} / \mathrm{ml}$ of NGF. All three concentrations of NGF significantly reduced the survival of the Bcl-2-transfected cell lines, the lower concentrations slightly but not significantly $(p>0.05)$ more than $100 \mathrm{ng} / \mathrm{ml}$. $D$, Anti-NGF antibody increases the survival of Bcl-2-transfected Schwann cells. Shown are the means \pm SEM, comparing the viability of three separate Bcl-2-transfected cell lines assayed in one survival experiment. Culture conditions were DMEM only, DMEM $+10 \mathrm{ng} / \mathrm{ml} \mathrm{NGF,} \mathrm{or} \mathrm{DMEM}+500 \mathrm{ng} / \mathrm{ml}$ anti-NGF antibody. The difference in survival between DMEM only and anti-NGF conditions was significant at $48 \mathrm{hr}(p=0.025)$, and the difference between NGF-neutralized (anti-NGF) and NGF-added conditions was significant at all time points ( $p$ values from 0.001 to 0.005 ).

plies, Poole, UK), coverslipped, and photographed using Ektachrome 200 ASA color slide film.

Flow cytometry. To determine whether the transfected Schwann cell lines expressed the human $\mathrm{Bcl}-2$ protein intracellularly, the cells were stained with anti-human Bcl-2 Ab as described previously (Strasser et al., 1995). Intracellular expression of CrmA protein from the CrmA plasmid was indirectly assessed by staining transfected cells with anti-Flag antibodies, using a similar protocol. Cell surface expression of p75 was determined by incubating the cells for $30 \mathrm{~min}$ on ice with $1 \mu \mathrm{g} / \mathrm{ml}$ mouse $\mathrm{mAb}$ clone 192 against rat $\mathrm{p} 75$, or with isotype-matched control mAb (anti-human CD40L). The cells were then washed twice with PBS containing $2 \% \mathrm{FCS}$ and $0.1 \%$ sodium azide, incubated for an additional 30 min with FITC-conjugated sheep anti-mouse IgG, washed twice, and analyzed using a FACScan flow cytometer (Becton Dickinson, Mountain View, CA).

To distinguish between apoptosis and necrosis, the pEF-1 and the Bcl-2\#1 transfected Schwann cell lines were cultured on 6-well plates in DMEM or DMEM containing $10 \mathrm{ng} / \mathrm{ml} \mathrm{NGF}$ for $48 \mathrm{hr}$. The cells were then trypsinized and washed once with DMEM/10\% FCS and twice with MT-PBS containing $2 \%$ FCS. A total of $10^{6}$ cells were incubated in $100 \mu \mathrm{l}$ of solution containing $20 \mu \mathrm{l}$ of Annexin-V-Fluos labeling reagent and $20 \mu \mathrm{l}$ of $50 \mu \mathrm{g} / \mathrm{ml}$ propidium iodide solution in $1 \mathrm{ml}$ of incubation buffer (10 mM HEPES/NaOH, pH 7.4, $140 \mathrm{~mm} \mathrm{NaCl}, 5 \mathrm{~mm} \mathrm{CaCl}_{2}$ ). After 15 min of incubation, $200 \mu \mathrm{l}$ of a HEPES and phosphate-buffered balanced salt solution containing 5\% FCS was added per tube, and the cells were immediately analyzed on a flow cytometer for fluorescein and propidium iodide detection.

Northern blotting. To confirm that the transfected clones were Schwann cells, transcripts of the Schwann cell glycoprotein $\mathrm{P}_{0}$ gene in untransfected and transfected Schwann cells were analyzed by Northern blotting, using a $1.85 \mathrm{~kb}$ probe that recognizes the Schwann cell-specific $\mathrm{P}_{0}$ RNA. The pSN63 plasmid containing the $P_{0}$ cDNA insert was a gift from $G$. Lemke (The Salk Institute, La Jolla, CA). Briefly, the $\mathrm{P}_{0}$ fragment was cut from the SN63 vector with EcoRI digestion, gel-purified using a QIAEX II gel extraction kit, and labeled with ${ }^{32} \mathrm{P}$ using a NeBlot kit (New England Biolabs, Beverly, MA). The labeled probe was hybridized overnight at $68^{\circ} \mathrm{C}$ with Schwann cell mRNA previously transferred to a Hybond-N membrane (Amersham). Images were developed after a $4 \mathrm{hr}$ exposure using a Phosphoimager (Molecular Dynamics, Sunnyvale, CA). In addition, Northern blotting was used to determine expression of the high-affinity NGF receptor Trk-A on the Bcl-2-transfected Schwann cell lines. A 398 bp fragment of Trk-A cDNA, cloned into the pBSKS(-) 


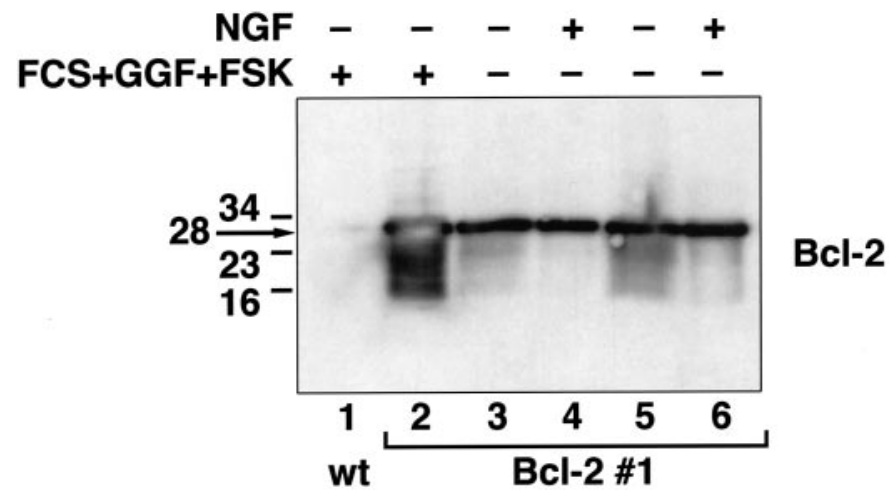

Figure 5. Nerve growth factor does not induce cleavage of Bcl-2. Western blotting of Bcl-2-transfected and control Schwann cells was performed to determine whether NGF induces cleavage of Bcl-2. Lane 1, Wild-type rat Schwann cells; lane 2, Bcl-2-transfected Schwann cells in serum, neuregulin- $\beta$, and forskolin; lanes 3 and 4 , survival factor-deprived condition for $24 \mathrm{hr}$; lanes 5 and 6 , survival factor-deprived condition for $72 \mathrm{hr}$. No cleavage product was detected when $10 \mathrm{ng} / \mathrm{ml}$ NGF was present in the survival factor-deprived conditions (lanes 4 and 6 ).

vector was a gift from Dr. R. Klein (EMBL, Heidelberg, Germany). The fragment was cut from the expression vector with EcoRI and $X b a \mathrm{I}$ digestion and gel-purified using a QIAquick gel extraction kit. A total of $50 \mathrm{ng}$ of purified DNA was labeled with ${ }^{32} \mathrm{P}$ as described above and hybridized overnight at $68^{\circ} \mathrm{C}$ with $0.5 \mu \mathrm{g}$ of mRNA isolated from Bcl-2\#1 cells and with $10 \mu \mathrm{g}$ of total RNA from PC12 neuronal cells as a positive control. Images were developed after a $72 \mathrm{hr}$ exposure using a Phosphoimager. To assess the amount of RNA loaded, the membrane was further hybridized with a 280 bp G3PD (GAPDH)-probe, cut with Pst I-HindIII digestion from a pGEM3Z plasmid.

Western blotting. Reduced and denatured protein samples from control and Bcl-2-transfected Schwann cells were run on a $4-15 \%$ SDS Tris-HCl gel (Bio-Rad, Richmond, CA), transferred to a polyvinylidene difluoride membrane, and blotted with Bcl-2-100 mAb. Bound antibodies were detected with HRP-conjugated sheep anti-mouse $\operatorname{IgG}$ (Silenius) and enhanced using chemiluminescence (Amersham).

$R T-P C R$. Degenerate primers amplifying a $549 \mathrm{bp}$ fragment from the coding region of exon 1 of the Rattus norvegicus Bcl-2 cDNA were designed with the aid of NCBI's Blast 2.0 sequence similarity search program. The upper primer was 5'-CGCAAGCCGGGAGAACAGGGTA-3', and the lower primer was 5'-AGGTGTGCAGATGCCGGTTCAGGT-3'. These primers were designed to maximize amplification of sequences similar in the rat, mouse, and human Bcl-2 genes, with minimal homology to other Bcl family members, and were synthesized by Beckman Oligonucleotide Synthesis Service (Gladesville, NSW, Australia). As a positive control, a $760 \mathrm{bp}$ fragment of rat $\beta$-actin was amplified using $5^{\prime}$-CTGAAGTACCCCATTGAACACGGC-3' as the upper primer and $5^{\prime}$-CAGGGCAGTAATCTCCTTCTGCAT-3' as the lower primer. The $\beta$-actin oligonucleotides were also designed using the Blast 2.0 computer program, and they were synthesized by Pacific Oligos (Southern Cross University Lismore, NSW, Australia).

To synthesize first-strand DNA for RT-PCR, total RNA $(1 \mu \mathrm{g})$ or mRNA (50 ng) isolated from wild-type rat Schwann cells was reversetranscribed using Superscript II RNase $\mathrm{H}^{-}$Reverse Transcriptase (Life Technologies) in a $20 \mu \mathrm{l}$ reaction volume at $42^{\circ} \mathrm{C}$. The various culture conditions from which RNA had been prepared were as follows: (1) DMEM containing $10 \%$ FCS, $10 \mathrm{ng} / \mathrm{ml}$ neuregulin- $\beta$, and $2 \mu \mathrm{M}$ forskolin, (2) DMEM containing IGF-1 for either 4 or $16 \mathrm{hr}$, (3) DMEM containing NGF for $4 \mathrm{hr}$, (4) DMEM only for $1,2,4,8$, or $24 \mathrm{hr}$. For RT-PCR, $5 \%(1 \mu \mathrm{l})$ of the first-strand reaction was amplified in a reaction containing $0.4 \mu \mathrm{l}$ of $10 \mathrm{~mm}$ dNTP mixture (Life Technologies), $1 \mu \mathrm{l}$ of each primer at $20 \mu \mathrm{M}, 1 \mu \mathrm{l}$ of $50 \mathrm{mM} \mathrm{MgCl}_{2}, 5 \mu \mathrm{l}$ of $10 \times$ PCR buffer (Life Technologies), and $0.5 \mu \mathrm{l}(2.5 \mathrm{U})$ of AmpliTag (Perkin-Elmer, Emeryville, CA) to a total volume of $50 \mu \mathrm{l}$. A total of 30 cycles of PCR amplification was performed on a Perkin-Elmer Cetus 480 thermal cycler (Perkin-Elmer) at $94^{\circ}$ for $1 \mathrm{~min}, 58^{\circ}$ for $1 \mathrm{~min}$, and $72^{\circ}$ for $2 \mathrm{~min}$. Reaction products were electrophoretically separated on a $2 \%$ DNA grade agarose gel containing $5 \mu \mathrm{g} / \mathrm{ml}$ ethidium bromide stain to facilitate visualization of the bands under UV illumination.

\section{RESULTS \\ Generation and characterization of Bcl-2- and CrmA- expressing Schwann cell lines}

To assess the effect of Bcl-2 and CrmA on Schwann cell survival we transfected primary rat Schwann cells with puromycinselectable constructs containing sequences encoding FLAG epitope-tagged human Bcl-2 or FLAG-tagged CrmA. Expression of the constructs in the stable puromycin-resistant rat Schwann cell lines that were generated was demonstrated by intracellular immunofluorescence staining with anti-human Bcl-2 antibodies or, in the case of the CrmA transfected cells, with anti-Flagantibodies. Three Bcl-2-transfected and three CrmA-transfected cell lines that expressed high and similar levels of Bcl-2 and CrmA, respectively, were chosen for further experiments (Fig. 1).

To confirm that the transfected cell lines had retained Schwann cell characteristics, all cell lines were assessed by immunohistochemistry for expression of the glial protein S-100. All of the transfected cell lines that were used in subsequent experiments expressed S-100. Bcl-2\#1 and CrmA\#14 cell lines staining positively for S-100 are shown in Figure 2. Northern blotting was used to confirm expression of the Schwann cell-specific $\mathrm{P}_{0}$ gene (Lemke and Axel, 1985). $\mathrm{P}_{0}$ was expressed in all three Bcl-2transfected cell lines that were studied as well as in wild-type rat Schwann cells but not in rat fibroblasts that were included as a negative control (Fig. 3).

\section{$\mathrm{Bcl}-2$ rescues Schwann cells from apoptosis triggered by withdrawal of survival factors but fails to rescue these cells from killing by NGF}

To elucidate the potential role of Bcl-2 in Schwann cell apoptosis, we assessed the viability of three separate Bcl-2-transfected rat Schwann cell lines in comparison with rat Schwann cell lines transfected with the empty mammalian expression plasmid $\mathrm{pEF}$ FLAGpGKpuro (pEF). The first death stimulus that was assessed was withdrawal of serum, neuregulin- $\beta$, and forskolin. All three Bcl-2-transfected cell lines exhibited significant survival advantage at 24, 48, and $72 \mathrm{hr}$ after factor deprivation in comparison with the pEF\#1 control cell line (Fig. 4A). Survival of the pEF\#1 and pEF\#2 control cell lines used in this study did not significantly differ from wild-type Schwann cells (data not shown).

The survival factor-starved Bcl-2-transfected cells were also cultured with NGF at the time of plating. Addition of NGF at 10 $\mathrm{ng} / \mathrm{ml}$ to the cultures reduced the viability of all three Bcl-2transfected cell lines throughout the $72 \mathrm{hr}$ observation period (Fig. 4B). There was a trend toward more cell death at the lower concentrations of NGF (1 and $10 \mathrm{ng} / \mathrm{ml}$ ) than at $100 \mathrm{ng} / \mathrm{ml}$, but

Table 1. Bcl-2-transfected Schwann cells are resistant to apoptosis induced by survival factor deprivation but undergo apoptosis in response to NGF

\begin{tabular}{lllll} 
& & PI- $(\%)$ & PI $+(\%)$ & Annexin $+(\%)$ \\
\hline pEF & - NGF & 1 & 98 & 98 \\
pEF & + NGF & 7 & 92 & 96 \\
Bcl-2\#1 & - NGF & 92 & 7 & 13 \\
Bcl-2\#1 & + NGF & 67 & 32 & 33
\end{tabular}

Control (pEF) and Bcl-2-transfected Schwann cells were deprived of serum, neuregulin- $\beta$, and forskolin for $48 \mathrm{hr}$. NGF $(10 \mathrm{ng} / \mathrm{ml})$ was added to half of the cultures. To determine the proportions of viable and apoptotic cells in each condition, the cells were detached and stained at $48 \mathrm{hr}$ with propidium iodide (PI) and Annexin-V-Fluos solution and analyzed by flow cytometry. Viable cells exclude propidium iodide and appear in the table as PI-. The data are generated from a single experiment. 


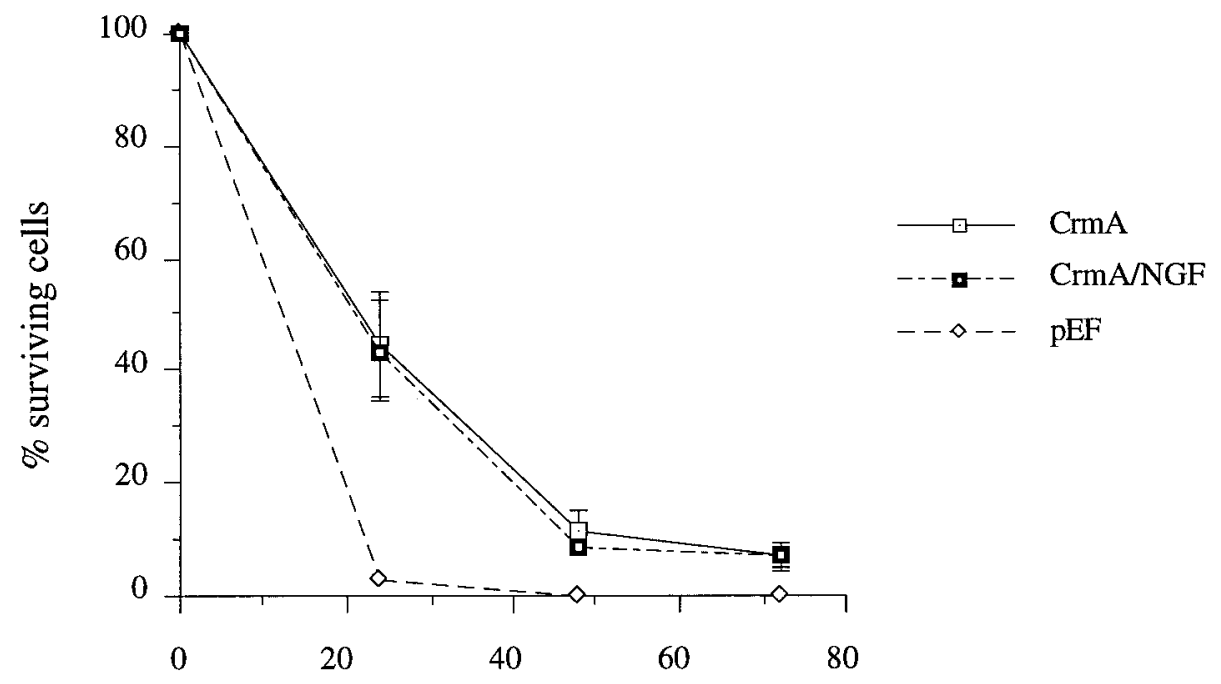

B

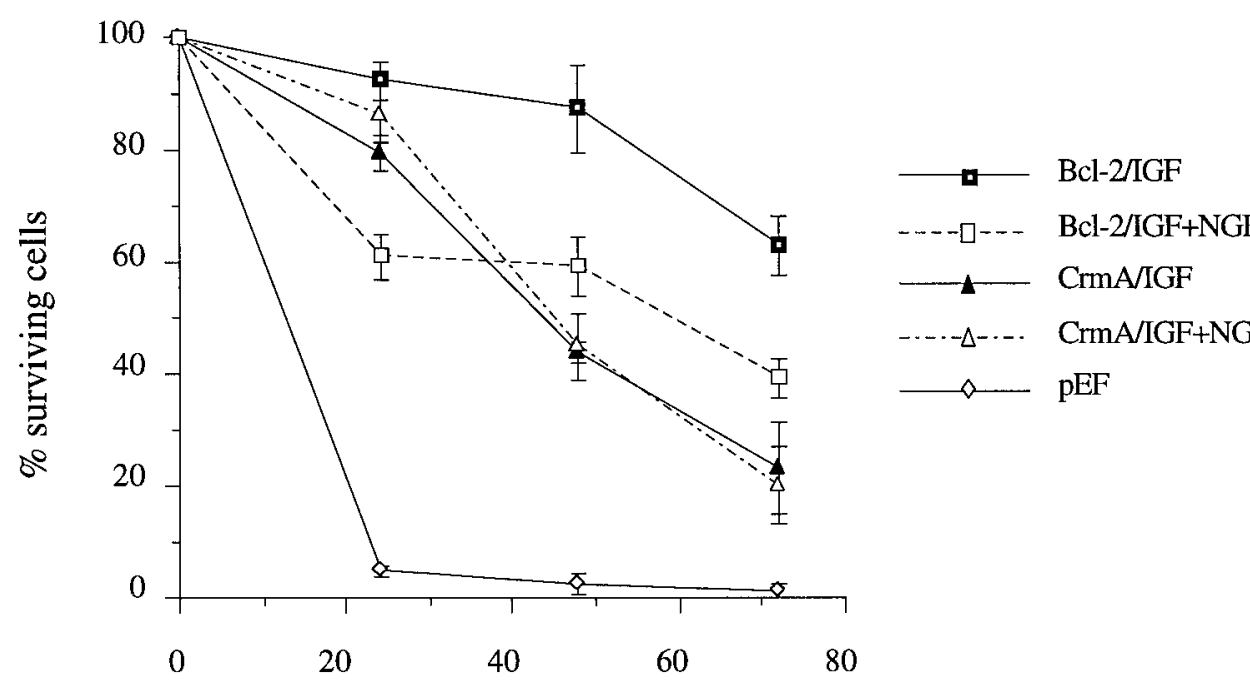

Figure 6. Survival analysis of CrmAtransfected rat Schwann cells in vitro after survival factor withdrawal or treatment with exogenous NGF. $A$, CrmA-transfected cells show delayed but retained susceptibility to survival factor deprivation but are protected against NGF killing. Shown are the mean viabilities \pm SEM of three separate CrmA-transfected Schwann cell lines (CrmA\#7, \#14, and \#15) in comparison with the pEF\#1 control cell line, as assessed in one of two similar survival experiments. Cell lines were cultured either in DMEM only or in DMEM containing $10 \mathrm{ng} / \mathrm{ml} \mathrm{NGF}$. Control pEF cells died rapidly in both conditions (only DMEM is shown). CrmA-transfected cells showed some abrogated death at $24 \mathrm{hr}$ ( $p=0.025)$, but by $72 \mathrm{hr}$ both the CrmA and control cells showed a similar death profile ( $p$ values 0.1 at $48 \mathrm{hr}$ and 0.15 at 72 hr; NS). $B$, CrmA-transfected cells are resistant to NGF killing in the presence of IGF-1, whereas Bcl-2-transfected Schwann cells remain susceptible to NGF under these conditions. Shown are means \pm SEM of three separate experiments using the cell lines Bcl-2\#1 and CrmA\#7. The cells were cultured in either DMEM containing $100 \mathrm{ng} / \mathrm{ml} \mathrm{IGF-1}$ or DMEM containing $100 \mathrm{ng} / \mathrm{ml} \mathrm{IGF-1} \mathrm{and} 10 \mathrm{ng} / \mathrm{ml}$ NGF. The difference in survival between the two culture conditions was significant for the Bcl$2 \# 1$ cell line ( $p$ values from 0.025 to $0.005)$, but not for the CrmA\#7 cell line $(p>0.05)$.

\section{Hours post withdrawal of serum, neuregulin, and forskolin}

the differences in viability between the various concentrations were not statistically significant (Fig. 4C). Viability of the vectoronly pEF\#1 cells was not significantly affected by the addition of NGF under conditions of survival factor deprivation, presumably because these cells were dying so rapidly (data not shown).

To quantitate viability, the survival factor-deprived and the NGF-treated Schwann cells were stained with Annexin, which labels apoptotic cells, and the cells were analyzed by flow cytometry (Table 1). After withdrawal of survival factors, most (98\%) of the control cells were Annexin positive at $48 \mathrm{hr}$, whereas only $13 \%$ of the Bcl-2\#1 Schwann cells were Annexin positive. How- ever, $33 \%$ of the survival factor-deprived Bcl-2\#1 Schwann cells cultured with NGF were Annexin positive at $48 \mathrm{hr}$ (Table 1). This correlated well with the survival advantage conferred by Bcl-2 and with the killing observed by NGF in the context of Bcl-2 expression, as assessed in the MTT assays.

Because Schwann cells have been reported to secrete low levels of NGF (Yamamoto et al., 1993), we next assessed the effect of neutralizing anti-NGF antibodies on the survival of the Bcl-2transfected Schwann cells. Previously, it had been established that exogenous NGF and anti-NGF antibodies have no effect on the viability of wild-type Schwann cells in basal conditions after 
Figure 7. Wild-type rat Schwann cells undergo apoptosis after survival factor deprivation, with no significant difference in viability with or without NGF $(p>0.05)$. However, $10 \mathrm{ng} / \mathrm{ml} \mathrm{NGF}$ significantly decreases Schwann cell viability when the cells are cocultured with IGF-1 and neuregulin- $\beta$. Means \pm SEM of three separate experiments are shown. The differences in survival between IGF$1+$ GGF and IGF-1+GGF+NGF conditions were significant at all time points assessed ( $p$ values $0.05,0.025$, and 0.005 at 24,48 , and $72 \mathrm{hr}$, respectively).

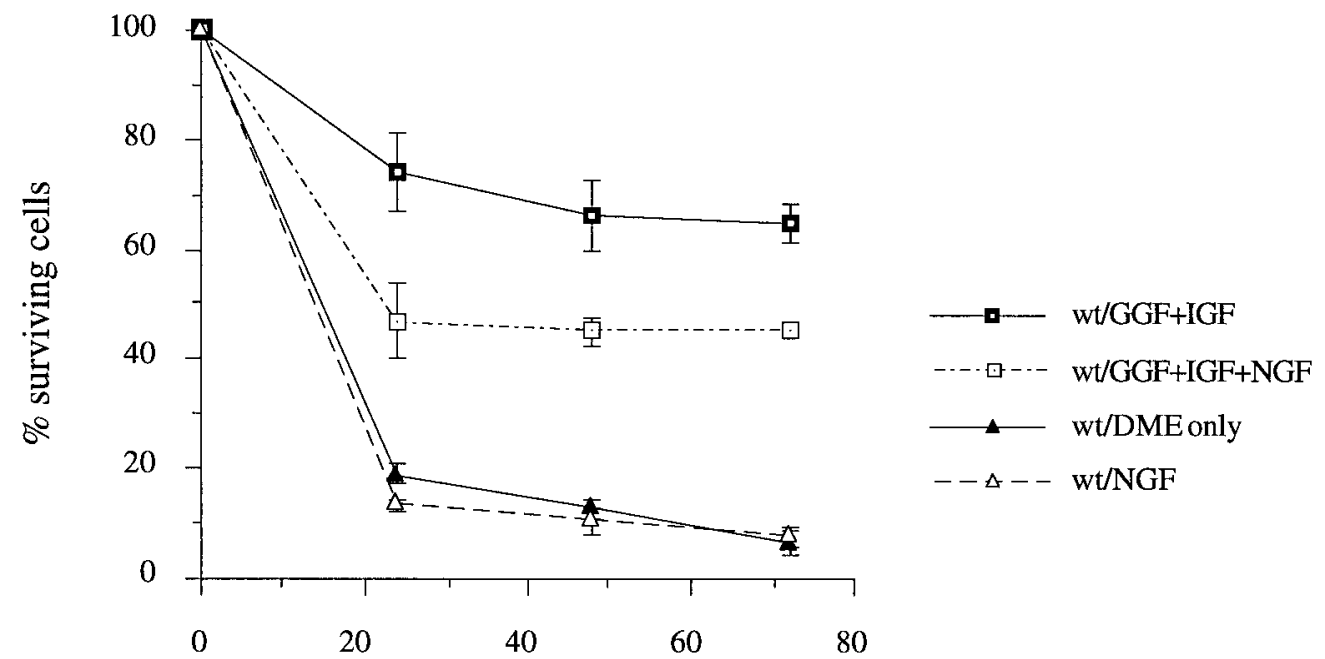

Hours post withdrawal of serum and forskolin

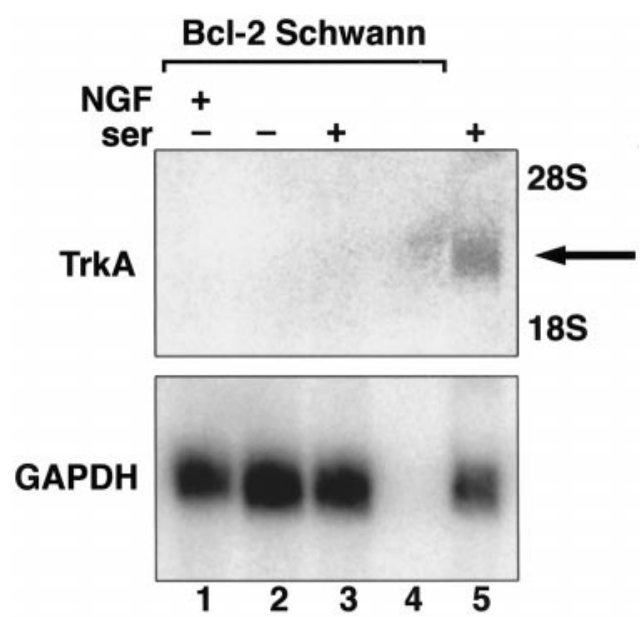

Figure 8. Transcripts of the high-affinity NGF receptor TrkA are not detectable in the Bcl-2-transfected Schwann cells. Northern blots were prepared using mRNA $(\sim 0.5 \mu \mathrm{g} /$ lane $)$ isolated from Bcl-2\#1 Schwann cells cultured in DMEM containing $10 \mathrm{ng} / \mathrm{ml} \mathrm{NGF}$ for $4 \mathrm{hr}$ (lane 1) or on survival factor withdrawal for $4 \mathrm{hr}$ (lane 2) or in DMEM containing serum, neuregulin- $\beta$, and forskolin (lane 3). Approximately $10 \mu \mathrm{g}$ of total RNA isolated from PC12 neuronal cells was loaded as a positive control in lane 5. The arrow indicates the TrkA transcript between the $28 \mathrm{~S}$ and $18 \mathrm{~S}$ ribosomal RNA bands that was detected in RNA isolated from the PC12 cells.

growth factor withdrawal (T. J. Kilpatrick, unpublished observation). We found that blocking the NGF activity increased the survival of all three growth factor-deprived Bcl-2-transfected cell lines by $20-25 \%$ (Fig. $4 D$ ). At $48 \mathrm{hr}$ the survival of Bcl-2transfected Schwann cells that were treated with anti-NGF antibodies was almost $100 \%$ and significantly higher than the survival of untreated cells. The difference in survival between cultures treated with exogenous NGF and those in which endogenous NGF activity was neutralized was $\sim 50 \%$ (Fig. $4 D$ ).

\section{NGF does not lead to cleavage of Bcl-2 in} Schwann cells

To determine whether cleavage of Bcl-2 could be involved in the NGF-induced killing of the Bcl-2-expressing Schwann cells, we prepared Western blots of Bcl-2-transfected Schwann cells. The Schwann cells were cultured with either serum, neuregulin-B, and forskolin or, alternatively, without these additives, either with or without NGF, for 24 or $48 \mathrm{hr}$. We used the same anti-human Bcl-2 100 antibody that was used for recognition of the cleaved $23 \mathrm{kDa}$ fragment by Cheng et al. (1997). The antibody specifically recognized the $28 \mathrm{kDa}$ noncleaved human $\mathrm{Bcl}-2$ protein in the Bcl-2transfected cells but, as expected, not endogenous Bcl-2 in the wild-type rat Schwann cells (Fig. 5). No cleavage of Bcl-2 was demonstrated (Fig. 5, lanes 4 and 6 ).

\section{CrmA delays but does not inhibit apoptosis triggered by survival factor withdrawal but protects against killing by NGF}

The effects of growth factor withdrawal and of exogenous NGF on the viability of CrmA-transfected Schwann cells were also assessed. The CrmA-transfected cell lines showed some potentiated survival in comparison to control cells at $24 \mathrm{hr}$ after withdrawal of survival factors, but by $72 \mathrm{hr}$ they showed a proportion of cell death similar to that of control cultures (Fig. 6A). Nerve growth factor did not decrease the survival of the growth factordeprived CrmA-transfected Schwann cells (Fig. 6A). To exclude the possibility that the death signal induced by survival factor withdrawal masked killing of the CrmA-transfected Schwann cells triggered by NGF, assays were also performed in the presence of IGF-1 to potentiate the baseline survival of the CrmA-transfected population. CrmA-transfected cells were also protected against NGF killing in these conditions (Fig. 6B), whereas Bcl-2transfected cells remained susceptible to NGF in the presence of IGF-1 (Fig. 6B).

\section{Wild-type Schwann cells are susceptible to killing by NGF in the presence of survival factors}

Survival factor-deprived wild-type rat Schwann cells died rapidly, and their survival was not significantly affected by NGF (Fig. 7). Because a death signal induced by NGF could not be assessed in cells that were already dying, we established conditions in which wild-type Schwann cells survived, but did not proliferate, by culturing them with IGF- 1 and neuregulin- $\beta$. In these conditions, addition of $10 \mathrm{ng} / \mathrm{ml}$ exogenous NGF decreased the viability of wild-type Schwann cells by $\sim 30 \%$ (Fig. 7). Thus, the susceptibil- 


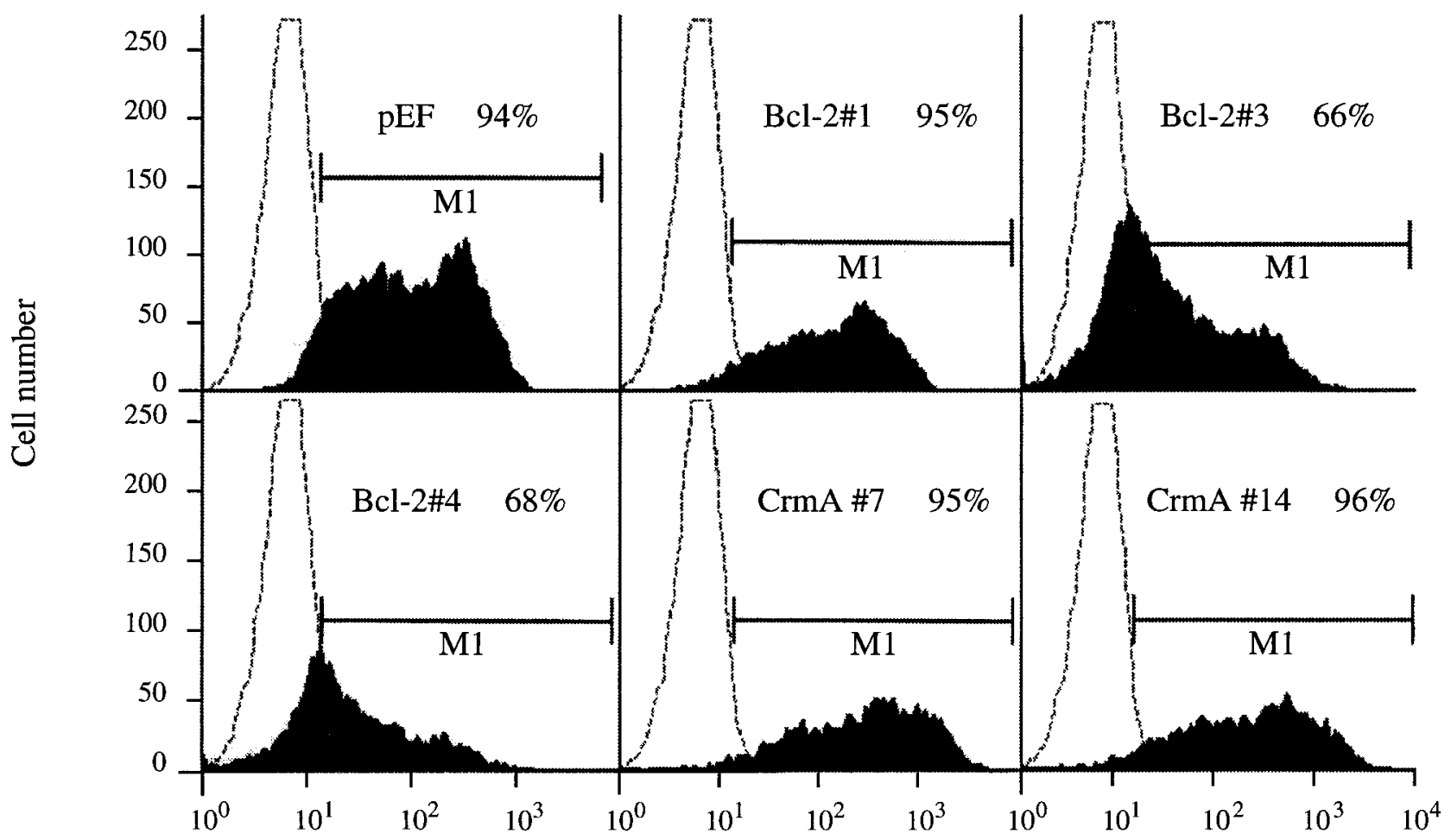

\section{Log Fluorescence}

Figure 9. Bcl-2-transfected, CrmA-transfected, and control rat Schwann cells express the low-affinity NGF receptor p75 on the cell surface. Approximately $10^{6} \mathrm{pEF}, \mathrm{Bcl}-2 \# 1, \mathrm{Bcl}-2 \# 3$, Bcl-2\#4, CrmA\#7, or CrmA\#14 cells were stained with mAb MC192 against the rat p75 receptor or with mouse IgG1 control mAb, followed by FITC-conjugated sheep anti-mouse IgG. Fluorescence was measured using a flow cytometer. The background fluorescence obtained with the isotype-matched control $\mathrm{mAb}$ (dotted lines) was subtracted from the total pool to enable calculation of the percentages of cells from each cell line that expressed p75 (labeled as the $M 1$ population).

ity of wild-type Schwann cells to NGF was similar to the susceptibility of the Bcl-2-transfected Schwann cells, once no other interfering death stimuli were operative.

\section{Expression of NGF receptors by the transfected Schwann cell lines}

The induction of wild-type Schwann cell death by NGF was likely to have been mediated by p75, because these cells have not been shown to express TrkA but they express high levels of p75 (Lemke and Chao, 1988; Yamamoto et al., 1993). To determine whether the NGF-mediated effects in the Bcl-2-transfected rat Schwann cell lines were mediated by $\mathrm{p} 75$, we assessed expression of TrkA by these cells by Northern blotting. No TrkA message was detectable in Bcl-2-transfected Schwann cells cultured for $4 \mathrm{hr}$ in DMEM containing serum, neuregulin- $\beta$, and forskolin, in DMEM alone, or in DMEM containing $10 \mathrm{ng} / \mathrm{ml}$ of NGF (Fig. 8). Expression of p75 was assessed by indirect immunofluorescence staining and flow cytometry. All of the cell lines expressed p75, with the CrmA lines appearing to express the receptor at the highest level (Fig. 9).

\section{p75-deficient Schwann cells are resistant to killing by NGF}

To establish whether NGF-mediated Schwann cell death required p75, we generated Schwann cell cultures from mice homozygous for a deletion in the p75 gene and from wild-type control mice. Unlike the wild-type rat Schwann cells that had been passaged several times in vitro, $\sim 25 \%$ of the wild-type mouse Schwann cells (second to third passage) survived $48 \mathrm{hr}$ without serum or neuregulin- $\beta$, and their survival was significantly decreased by NGF added at the time of plating (Fig. 10) $(p<0.0005)$. In contrast, the Schwann cells isolated from p75 knockout mice were completely resistant to NGF killing (Fig. 10). As we have shown before (our unpublished results), the p75-deficient Schwann cells also exhibited a survival advantage in comparison with the wildtype mouse Schwann cells on survival factor deprivation (Fig. 10).

\section{Expression of the $\mathrm{Bcl}-2$ gene is regulated by wild-type Schwann cells}

Regulation of Bcl-2 expression in wild-type rat Schwann cells was studied using RT-PCR. Bcl-2 mRNA was expressed in all culture conditions that promoted survival, including IGF-1 alone, throughout the $16 \mathrm{hr}$ assay period (Fig. 11). In contrast, after $2 \mathrm{hr}$ of serum, neuregulin- $\beta$, and forskolin withdrawal, Bcl- 2 mRNA expression was downregulated to an undetectable level (Fig. 11). However, when NGF was present in the media, after the withdrawal of serum and other survival factors, Bcl-2 could be still detected at $4 \mathrm{hr}$, suggesting that NGF, at least in the short term, maintained Bcl-2 expression (Fig. 11).

\section{DISCUSSION}

Rat Schwann cell lines that stably express either human Bcl-2 or a poxvirus caspase inhibitor, CrmA, were used to investigate the 

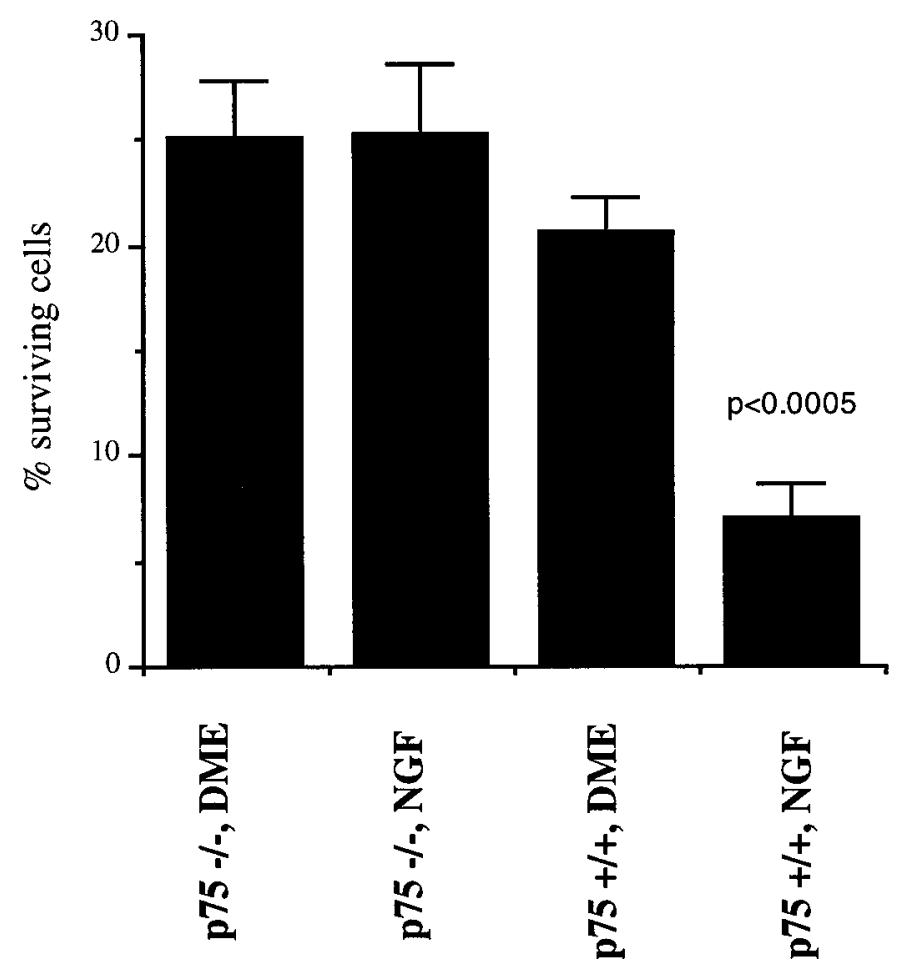

Figure 10. Schwann cells isolated from p75 knockout mice are resistant to NGF killing, whereas wild-type mouse Schwann cells are susceptible. The viability of Thy-1.2-sorted, p75 ${ }^{-1-}$ and $\mathrm{p} 75^{+/+}$Schwann cells was assessed at $48 \mathrm{hr}$ after FCS and neuregulin- $\beta$ withdrawal, with or without $10 \mathrm{ng} / \mathrm{ml}$ NGF. Shown is the mean viability \pm SEM of cells cultured in six parallel wells for each condition as assessed in one of two survival experiments, each with similar results.

mechanisms that effect Schwann cell survival in response to different death stimuli, either survival factor deprivation or a stimulus initiated by NGF, signaling through its low-affinity receptor $\mathrm{p} 75$. The results indicated that Bcl-2 protected Schwann cells from apoptosis induced by survival factor deprivation, whereas CrmA did not. This is consistent with previously established differential roles for $\mathrm{Bcl}-2$ and $\mathrm{CrmA}$ as inhibitors of apoptosis: Bcl-2 blocks apoptosis induced by a wide variety of insults, apparently acting by inhibiting adaptors required for activation of certain caspases such as caspase 9 (Strasser et al., 1995; Adams and Cory, 1998), whereas CrmA appears to be more effective in blocking TNF family receptor-mediated apoptosis, by inhibiting caspase 8 (Smith et al., 1996; Ashkenazi and Dixit, 1998). Our results confirm a functional dichotomy in the regulation of Schwann cell death into Bcl-2 inhibitable and CrmAinhibitable death pathways, although the death of neurons after deprivation of NGF is blockable by either Bcl-2 (Park et al., 1996) or CrmA (Gagliardini et al., 1994). It is thus possible that the pathways of cell death initiated by loss of trophic support are different in Schwann cells and neurons. This is consistent with emerging in vivo data that suggest coexistence of several different, not only stimulus-specific but also cell type-specific, apoptotic pathways in mammalian cells (Hakem et al., 1998).

Several neuronal cell types die in response to NGF, including sensory dorsal root ganglion neurons (Barrett and Bartlett, 1994), neuronal precursors in embryonic chicken retina (Frade et al., 1996), and cholinergic forebrain neurons (Van der Zee et al., 1996). In at least three instances, this mechanism has been demonstrated to contribute to developmentally regulated death of neurons in vivo (Frade et al., 1996; Van der Zee et al., 1996; Bamji et al., 1998). In addition, mature oligodendrocytes that express p75, but not TrkA, are susceptible to NGF-induced cell death, whereas oligodendrocyte precursors and astrocytes are resistant (Casaccia-Bonnefil et al., 1996). Similarly, the Bcl-2-transfected Schwann cell lines that we have analyzed did not express TrkA mRNA (Fig. 8), whereas p75 was expressed at high levels (Fig. 9). The effect of p75 activation, however, is almost certainly contextural, as demonstrated by the resistance of the CrmA-transfected Schwann cells to killing by NGF (Fig. 6A). CrmA is quite selective in its ability to inhibit caspases, showing the highest affinities to caspase 1 (interleukin- $1 \beta$ converting enzyme) and caspase 8 (Zhou et al., 1997; Garcia-Calvo et al., 1998). Therefore, activation of caspase 1 or caspase 8 or both, in addition to expression of p75 in the absence of TrkA, is likely to be necessary for induction of cell death by NGF. High levels of the Bcl-2 transgene expressed in Schwann cells, or alternatively, culture of wild-type Schwann cells in conditions that maintained their viability and Bcl-2 expression, were permissive for killing induced by exogenous NGF, suggesting that NGF was killing via a Bcl-2-independent pathway. Schwann cells isolated from mice lacking a functional p75 receptor were resistant to the NGF-induced cell death, corroborating that the NGF killing was mediated by $\mathrm{p} 75$.

Schwann cells secrete NGF (Lindholm et al., 1987), and we found that inhibition of endogenous NGF activity resulted in a significant increase in the viability of survival factor-deprived Bcl-2-transfected Schwann cells. This suggests that incomplete protection of the Bcl-2-transfected Schwann cells against survival factor deprivation was caused by death induced by endogenous NGF. Death-inducing activity of endogenous NGF could also explain the observed inferior survival of wild-type mouse Schwann cells in comparison with the p75-deficient mouse Schwann cells after survival factor deprivation (Fig. 10). Moreover, our results argue against a role for constitutive deathinducing activity of p75 in the absence of ligand binding (Rabizadeh et al., 1993) in this lineage, because prevention of ligand binding increased survival rather than induced death.

The Bcl-2 family is regulated by cytokines and other death/ survival signals (Adams and Cory, 1998). Using RT-PCR we confirmed that wild-type Schwann cells express Bcl-2 mRNA. We also demonstrated early downregulation of Bcl-2 transcript expression in Schwann cells after survival factor deprivation (Fig. 11). This supports a role for Bcl-2 in the maintenance of Schwann cell viability induced by survival factors. Detailed analysis of the nervous systems of $\mathrm{Bcl}-2^{-1-}$ mice has indicated progressive loss of neurons during early postnatal development, but the effects on Schwann cell numbers ensheathing surviving neurons or the effects on Schwann cell survival after axotomy remain unexplored (Michaelidis et al., 1996). Preliminary experiments using ribonuclease protection assays have suggested that Bcl-2 is indeed expressed by postnatal Schwann cells in wild-type animals both in the quiescent state and after axotomy (D. Syroid and G. Lemke, unpublished observations). Further analyses of these expression patterns will form the basis for understanding the potential physiological relevance of $\mathrm{Bcl}-2$ as a modulator of Schwann cell survival.

Previously, it has been established that axotomy leads to potentiated apoptosis among Schwann cells deprived of axonal contact (Grinspan et al., 1996; Syroid et al., 1996). If Bcl-2 were upregulated after nerve injury in response to cytokines released at the lesion site (Creange et al., 1997), this would facilitate the survival of Schwann cells in the distal stump. Downregulation of 


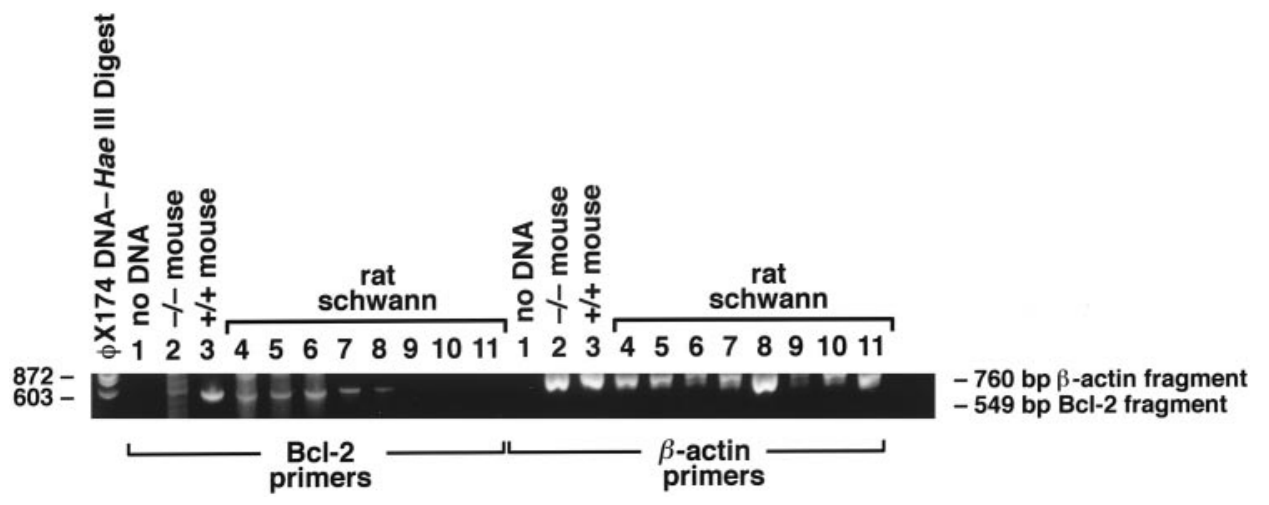

Figure 11. Regulation of Bcl-2 expression in wild-type rat Schwann cells as studied by RT-PCR. Bcl-2 expression was detected in cells cultured in IGF-1 for $4 \mathrm{hr}$ (lane 4), IGF-1 for $16 \mathrm{hr}$ (lane 5), NGF for $4 \mathrm{hr}$ (lane 6), and after withdrawal of FCS, neuregulin- $\beta$, and forskolin for $1 \mathrm{hr}$ (lane 7 ) or $2 \mathrm{hr}$ (lane 8 ). Bcl-2 was downregulated to undetectable levels after 4,8 , and $24 \mathrm{hr}$ of survival factor deprivation (lanes 9-11). Rat $\beta$-actin was amplified as control to verify the fidelity of the cDNA. A $\phi X 174-$ Hae III digest in lane 0 served as a molecular weight marker. Negative controls included no DNA in lane 1 and tail DNA from a Bcl-2 knockout mouse $\left(\mathrm{Bcl}-2^{-/}\right)$in lane 2. Tail DNA from a Bcl-2 wild-type littermate of the $\mathrm{Bcl}-2^{-/-}$mouse served as a positive control (lane 3, Bcl-2 $2^{+/+}$).

Bcl-2 expression by Schwann cells that completely lose access to axonally derived neuregulins (Grinspan et al., 1996) and IGF-1 (Syroid et al., 1999) would increase their susceptibility to apoptosis.

Our results also suggest an alternative mechanism by which the cells could die. Schwann cells upregulate their $\mathrm{p} 75$ expression and production of NGF after axotomy (Lindholm et al., 1987; Lemke and Chao, 1988; Taniuchi et al., 1988). This could facilitate the presentation of NGF to regenerating axons (Taniuchi et al., 1988). In this context, Schwann cells that fail to make a viable contact with the regenerating axons and subsequently fail to present NGF to them could be eliminated via continued activation of p75, even if Bcl-2 expression is maintained. Early and robust invasion of macrophages is also a feature in peripheral nerve injury and has been hypothesized to contribute to peripheral nerve degeneration (Franzen et al., 1998). Macrophages, like Schwann cells, can release NGF, and it is of note that microgliaderived NGF induces apoptosis in embryonic chick retinal neurons (Frade et al., 1996; Frade and Barde, 1998). Thus it is possible that infiltrating macrophages contribute to the induction of Schwann cell death. This could be useful in the killing of supernumerary Schwann cells, but if unchecked could lead to excessive cell death and thus limit peripheral nerve repair. A potential role of NGF in mediating Schwann cell death could have important implications for the ongoing clinical trials in which NGF is being assessed as a potential therapeutic agent for peripheral neuropathies (Rogers, 1996; Apfel et al., 1998).

Little is known about the intracellular pathways that mediate p75-induced apoptosis, although the molecular events that signal downstream of the related molecule TNFR have been investigated extensively (Ashkenazi and Dixit, 1998). Regulation of transcription factor expression is likely to be implicated, because inhibition of both NF- $\kappa \mathrm{B}$ and JNK/AP1 pathways sensitizes cells to apoptosis induced by TNF (Beg and Baltimore, 1996; Roulston et al., 1998). Moreover, aspartyl-glutamyl-valyl-aspartyl (DEVD)specific caspases appear to participate in TNF-mediated apoptosis only when NF- $\kappa \mathrm{B}$ is inhibited (Wang et al., 1998). Overexpression of Bcl-2 in PC12 neuronal cells has been shown to block JNK activation caused by growth factor withdrawal (Park et al., 1996). It remains to be investigated whether blockade of JNK (or $\mathrm{NF}-\kappa \mathrm{B}$ ) also occurs in Bcl-2-expressing Schwann cells and whether this inhibition increases the susceptibility to p75mediated cell death.

\section{REFERENCES}

Adams JM, Cory S (1998) The Bcl-2 protein family: arbiters of cell survival. Science 281:1322-1326.

Anton ES, Weskamp G, Reichardt LF, Matthew WD (1994) Nerve growth factor and its low-affinity receptor promote Schwann cell migration. Proc Natl Acad Sci USA 91:2795-2799.

Apfel SC, Kessler JA, Adornato BT, Litchy WJ, Sanders C, Rask CA (1998) Recombinant human nerve growth factor in the treatment of diabetic polyneuropathy. NGF Study Group. Neurology 51:695-702.

Ashkenazi A, Dixit VM (1998) Death receptors: signaling and modulation. Science 281:1305-1308.

Bamji SX, Majdan M, Pozniak CD, Belliveau DJ, Aloyz R, Kohn J, Causing CG, Miller FD (1998) The p75 neurotrophin receptor mediates neuronal apoptosis and is essential for naturally occurring sympathetic neuron death. J Cell Biol 140:911-923.

Barrett GL, Bartlett PF (1994) The p75 nerve growth factor receptor mediates survival or death depending on the stage of sensory neuron development. Proc Natl Acad Sci USA 91:6501-6505.

Beg AA, Baltimore D (1996) An essential role for NF-kappaB in preventing TNF-alpha-induced cell death. Science 274:782-784.

Brockes JP, Fields KL, Raff MC (1979) Studies on cultured rat Schwann cells. I. Establishment of purified populations from cultures of peripheral nerve. Brain Res 165:105-118.

Carter BD, Kaltschmidt C, Kaltchhmidt B, Offenhauser N, BohmMatthaei R, Baeuerle PA, Barde YA (1996) Selective activation of the NF-kB by nerve growth factor through the neurotrophin receptor $\mathrm{p} 75$. Science 272:542-545.

Casaccia-Bonnefil P, Carter BD, Dobrowsky RT, Chao MV (1996) Death of oligodendrocytes mediated by the interaction of nerve growth factor with its receptor p75. Nature 383:716-719.

Cheng EHY, Kirsch DG, Clem RJ, Ravi R, Kastan MB, Bedi A, Ueno K, Hardwick JM (1997) Conversion of Bcl-2 to a Bax-like death effector by caspases. Science 278:1966-1968.

Chinnaiyan AM, O'Rourke K, Tewari M, Dixit VM (1995) FADD, a novel death domain-containing protein, interacts with the death domain of Fas and initiates apoptosis. Cell 81:505-512.

Cohen GM (1997) Caspases: the executioners of apoptosis. Biochem J 326:1-16.

Creange A, Barlovatz-Meimon G, Gherardi RK (1997) Cytokines and peripheral nerve disorders. Eur Cytokine Netw 8:145-151.

Frade JM, Barde YA (1998) Microglia-derived nerve growth factor causes cell death in the developing retina. Neuron 20:35-41.

Frade JM, Rodriguez-Tebar A, Barde YA (1996) Induction of cell death by endogenous nerve growth factor through its $\mathrm{p} 75$ receptor. Nature 383:166-168.

Franzen R, Schoenen J, Leprince P, Joosten E, Moonen G, Martin D 
(1998) Effects of macrophage transplantation in the injured adult rat spinal cord: a combined immunocytochemical and biochemical study. J Neurosci Res 51:316-327.

Gagliardini V, Fernandez P-A, Lee RKK, Drexler HCA, Rotello RJ, Fishman MC, Yan J (1994) Prevention of vertebrate neuronal death by the crmA gene. Science 263:824-828.

Garcia-Calvo M, Peterson EP, Leiting B, Ruel R, Nicholson DW, Thornberry NA (1998) Inhibition of human caspases by peptide-based and macromolecular inhibitors. J Biol Chem 273:32608-32613.

Grinspan JB, Marchionni MA, Reeves M, Coulaloglou M, Scherer SS (1996) Axonal interactions regulate Schwann cell apoptosis in developing peripheral nerve: neuregulin receptors and the role of neuregulin. J Neurosci 16:6107-6118.

Hakem R, Hakem A, Duncan GS, Henderson JT, Woo M, Soengas M, Elia A, la Pompa JL, Kagi D, Khoo W, Potter J, Yoshida R, Kaufman SA, Lowe SW, Penninger JM, Mak TW (1998) Differential requirement for caspase 9 in apoptotic pathways in vivo. Cell 94:339-352.

Heumann R, Lindholm D, Bandtlow C, Meyer M, Radeke MJ, Misko TP, Shooter E, Thoenen H (1987) Differential regulation of mRNA encoding nerve growth factor and its receptor in rat sciatic nerve during development, degeneration and regeneration: role of macrophages. Proc Natl Acad Sci USA 84:8735-8739.

Huang DC, Cory S, Strasser A (1997) Bcl-2, Bcl-XL and adenovirus protein E1B19kD are functionally equivalent in their ability to inhibit cell death. Oncogene 14:405-414.

Itoh N, Yonehara S, Ishii A, Yonehara M, Mizushima S, Sameshima M, Hase A, Seto Y, Nagata S (1991) The polypeptide encoded by the cDNA for human cell surface antigen Fas can mediate apoptosis. Cell 66:233-243.

Kaplan D, Hempstead B, Martin-Zanca D, Chao M, Parada L (1991) The trk proto-oncogene product: a signal transducing receptor for nerve growth factor. Science 252:554-558.

Kaplan DR, Miller FD (1997) Signal transduction by the neurotrophin receptors. Curr Opin Cell Biol 9:213-221.

Lee KF, Bachman K, Landis S, Jaenisch R (1992) Dependence on p75 for innervation of some sympathetic targets. Science 263:1447-1449.

Lemke G, Axel R (1985) Isolation and sequence of a cDNA encoding the major structural protein of peripheral myelin. Cell 40:501-508.

Lemke G, Chao M (1988) Axons regulate Schwann cell expression of the major myelin and NGF receptor genes. Development 102:499-504.

Lindholm D, Heumann R, Meyer M, Thoenen H (1987) Interleukin-1 regulates synthesis of nerve growth factor in non-neuronal cells of rat sciatic nerve. Nature 330:658-659.

Meakin SO, Shooter EM (1992) The nerve growth factor family of receptors. Trends Neurosci 15:323-331.

Michaelidis TM, Sendtner M, Cooper JD, Airaksinen MS, Holtmann B, Meyer M, Thoenen H (1996) Inactivation of bcl-2 results in progressive degeneration of motoneurons, sympathetic and sensory neurons during early postnatal development. Neuron 17:75-89.

Newton K, Strasser A (1998) The Bcl-2 family and cell death regulation. Curr Opin Genet Dev 8:68-75.

Nicholson DW, Thornberry NA (1997) Caspases: killer proteases. Trends Biochem Sci 22:299-306.
Park DS, Stefanis L, Yan CYI, Farinelli SE, Greene LA (1996) Ordering the cell death pathway. J Biol Chem 271:21898-21905.

Pezzella F, Tse AG, Cordell JL, Pulford KA, Gatter KC, Mason DY (1990) Expression of the bcl-2 oncogene protein is not specific for the 14;18 chromosomal translocation. Am J Pathol 137:225-232.

Rabizadeh S, Oh J, Zhong L, Yang J, Bitler CM, Butcher LL, Bredesen DE (1993) Induction of apoptosis by the low-affinity NGF receptor. Science 261:345-348.

Rogers BC (1996) Development of recombinant human nerve growth factor (rhNGF) as a treatment for peripheral neuropathic disease. Neurotoxicology 17:865-870.

Roulston A, Reinhard C, Amiri P, Williams LT (1998) Early activation of c-Jun N-terminal kinase and p38 kinase regulate cell survival in response to tumor necrosis factor a. J Biol Chem 273:10232-10239.

Smith KG, Strasser A, Vaux DL (1996) CrmA expression in T lymphocytes of transgenic mice inhibits CD95 (Fas/APO-1)-transduced apoptosis, but does not cause lymphadenopathy or autoimmune disease. EMBO J 15:5167-5176.

Strasser A, Harris A, Huang DC, Krammer PH, Cory S (1995) Bcl-2 and Fas.APO-1 regulate distinct pathways to lymphocyte apoptosis. EMBO J 14:6136-6147.

Syroid DE, Maycox PR, Burrola PG, Liu N, Wen D, Lee KF, Lemke G, Kilpatrick TJ (1996) Cell death in the Schwann cell lineage and its regulation by neuregulin. Proc Natl Acad Sci USA 93:9229-9234.

Syroid DE, Zorick TS, Arbet-Engels C, Kilpatrick TJ, Eckhart W, Lemke G (1999) A role for insulin-like growth factor-1 in the regulation of Schwann cell survival. J Neurosci 19:2059-2068.

Taniuchi M, Clark HB, Schweitzer JB, Johnson EMJ (1988) Expression of nerve growth factor receptors by Schwann cells of axotomized peripheral nerves: ultrastructural location, suppression by axonal contact, and binding properties. J Neurosci 8:664-681.

Trachtenberg JT, Thompson WJ (1996) Schwann cell apoptosis at developing neuromuscular junctions is regulated by glial growth factor. Nature 379:174-177.

Van der Zee CE, Ross GM, Riopelle RJ, Hagg T (1996) Survival of cholinergic forebrain neurons in developing p75NGFR-deficient mice. Science 274:1729-1732.

Wang C-Y, Mayo MW, Korneluk RG, Goeddel DV, Baldwin Jr AS (1998) NF-kB antiapoptosis: induction of TRAF1 and TRAF2 and c-IAP1 and c-IAP2 to suppress caspase-8 activation. Science 281:1680-1683.

Yamamoto M, Sobue G, Li M, Arakawa Y, Mitsumata T, Kimata K (1993) Nerve growth factor (NGF), brain-derived neurotrophic factor (BDNF) and low-affinity nerve growth factor receptor (LNGFR) mRNA levels in cultured rat Schwann cells: differential time- and dose-dependent regulation by cAMP. Neurosci Lett 152:37-40.

Yoon SO, Casaccia-Bonnefil P, Carter B, Chao MV (1998) Competitive signaling between TrkA and p75 nerve growth factor receptors determines cell survival. J Neurosci 18:3273-3281.

Zhou Q, Snipas S, Orth K, Muzio M, Dixit VM, Salvesen GS (1997) Target protease specificity of the viral serpin CrmA. Analysis of five caspases. J Biol Chem 272:7797-7800. 